\section{INEFFICIENCY AMONG NON- ACADEMIC STAFFS IN NIGERIAN TERTIARY INSTITUTIONS: THE ROLE OF TRAINING AND DEVELOPMENT}

\begin{abstract}
Inefficiency has been a major issue battling the service delivery of non-academic staff in most public universities in Nigeria and this has greatly affected the academic and research outlook of Nigerian universities. Interest in the study was to determine the extent to which induction, demonstration, on-the-job and formal training which are all elements of employee training and development enhance managerial efficiency by looking at employee productivity and quality of service delivery. The study adopts a convenience and stratified sampling technique to select 293 non-academic staffs in selected public universities in Nigeria and the analysis was carried out using the structural equation model (SEM). The results revealed that on-the-job training has a significant negative relationship with the quality of service delivery in Nigerian universities $(t=-4.454),(p<0.05)$ and $B=-0.20$ ) which could be because most Nigerian universities do not deliberately place new employees to learn directly from a current employee in order to improve their performance. Hence, the study demonstrates that the only way to resolve inefficiency among non-academic (administrative) staff in public tertiary institutions is to integrate effective training into employee career management and adopt employee performance evaluation process as contained in the private organizations.
\end{abstract}

\section{KEYWORDS}

Demonstration training, employee productivity, induction training, non-academic staffs, on-thejob training, service delivery

\section{HOW TO CITE}

Adejare B. O., Olaore G. O., Udofia E. E., Emola T. B. (2020) 'Inefficiency Among NonAcademic Staffs in Nigerian Tertiary Institutions: the Role of Training and Development', Journal on Efficiency and Responsibility in Education and Science, vol. 13, no. 2, pp. 56-66. http://dx.doi.org/10.7160/eriesj.2020.130201

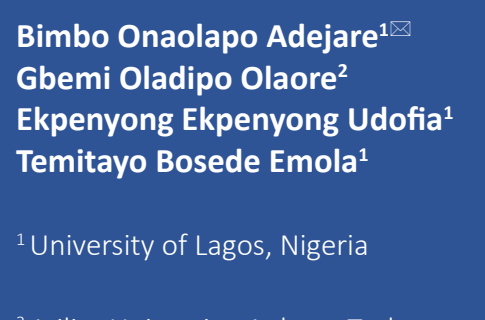

${ }^{2}$ Atilim University, Ankara, Turkey

bimboadejare@gmail.com

\section{Article history}

Received

January 23, 2020

Received in revised form

March 3, 2020

Accepted

April 24, 2020

Available on-line

June 30, 2020

Highlights

- Inefficient employees in an organization can cause a total breakdown in the flow of activities and the achievement of timely organizational results.

- Formal training of employees significantly affect employee productivity.

- Induction training of employees significantly affect the quality of service delivery.

- Inefficiency among non-academic staff can be traced to nepotism, mismanagement, bureaucratic bottle-neck in Nigerian tertiary institutions.

\section{INTRODUCTION}

The importance of employees in organizations goes a long way to determine the success of a business enterprise. This is because employees determine the flow and usage of organizational resources. In the word of Moulik and Mazumdar (2012) they are regarded as the active resources that an organization can possess as they are responsible for the usage of other resources of an organization in order to help organization achieve its goal and objectives. The business environment of an organization of today requires that organizations retain their knowledge capital (employees) such that they will be able to compete successfully in a dynamic and ever-changing business environment. The universities system requires the services of employees who are competent, motivated, well-trained and can successfully support the university academician to carry out research in an effective manner in order to achieve the goal and objective of the university both in the local and global environment (Obeidat, Masa'deh and Abdallah, 2014). 
Training and development of employees is an essential determinant of employee effectiveness and efficiency in the organization. It goes a long way to help organization remain competitive and relevant in the dynamic and technological business world of today. Training is seen as a way through which organization gauges the inefficient part of employee work behaviour in the organization. The importance of training on employees in organizations of today is fast rising such that it is consistently required for employees to remain productive and motivated to perform optimally in the organization (Samuel and Chipunza, 2013). This means that continuous training and development of employees have gradually become the only means of survival in organizations due to the technological business era where most business operations have become digitalized. Similarly, the performance of a firm has consistently become a topic of discussion among management of an organization regardless of the short and long term goals on sight. This is because the performance of an organization is dependent on several factors in the organization among which are employee productivity, employee job satisfaction, employee attrition and employee retainer-ship all of which determine the success, profitability, and survival of an organization (Tettey, 2010). This shows that training and developing employees for better performance in organization determine whether organization will succeed or not.

Additionally, tertiary institutions are saddled with the responsibility of training and empowering people with the required skills necessary for successful integration into the workforce of an economy. Thus, training and developing university administrators in tertiary institutions go a long way to help the university system achieve the purpose and objectives through which it is set up (Abdullah, Ahsan and Alam, 2009). University administrators are expected to support the work of academicians in a university system to produce and train skilled workforce such that they will be able to critically think and solve community and society problems. Notably, effective training and development of university administrators go a long way to enhance the success of tertiary institutions to remain relevant and be well rated in both local and global environments. Obeidat et al., (2014) state that managerial components such as motivation, staffing, employee development, career management, and employee welfares need to be consistently emphasized by university management to ensure workforce development and readiness to cope with technological tools necessary for effective and efficient work delivery.

Furthermore, organization (university management) needs to recruit competent and qualified administrators that will support the educational services of the university system. This is because recruiting the right employees for the right jobs helps organization to remain focus in achieving their aims and objectives for which it was set up (Mackelprang, Jayaram and $\mathrm{Xu}, 2012$ ). Effective training and development practices in the organization are important to enhance administrative and academic performance because it helps to improve university ratings, research capability, academic reputation and research contribution within the domestic and international community (Mathis and Jackson, 2011). The dynamic business environment as a result of technological innovation requires an effective strategy to be put in place to improve the educational services of both the academic and non-academic staff of an institution.

Hence, the non-academic staff of a university is the support system through which the success of the academician and students in a university relies upon. Most Nigerian universities are experiencing inefficiency and unproductivity among their staff and this is due to inappropriate possession of requisite skills in the institution's (Ng'ethe, Iravo and Namusonge, 2012). Inefficiency has grossly affected administrative staffs' performance which indirectly has reflected in the rating of the university especially when it comes to collaboration with the international community regarding issues affecting the university students and academic staff. The training and development of university administrators have greatly suffered recognition and this has affected the work of academicians in areas such as their research quality, academic services, teaching effectiveness and efficiency, university rating among others (Abeba, Mesele and Lemessa, 2015). Finally, this research was deemed important after reviewing thirty-five peer-review journals written on training and development and observed that elements of training such as (induction, on-thejob and demonstration training) have never been worked on especially with regards to non-academic staffs in the Nigerian public universities system. This, therefore, becomes the major contributions that this study intends to contribute to knowledge. The study also adds to the body of knowledge by looking at managerial efficiency from the angle of nonacademic staff quality of service delivery and productivity which have remained idle from previous work of other authors on the subject matter especially in Nigerian public tertiary institutions contexts.

\section{Human Resource Based Theory}

The success of an organization is heavily dependent on the active resources of an organization and these active resources are the human capital that determines the usage of the passive resources for an organization (Armstrong, 2009). The human resources are the pool of employees that are under the influence of employer especially in a contractual relationship within an organization. Organizations need human beings to achieve set goals and objectives and to enhance organization competitive edge especially among competing firms within an industry. Thus, the human resource-based theory is hinged on the importance of human beings for the successful establishment and competitive performance of a business enterprise. The theory relies on two assumptions for a successful competitive advantage in an organization (McDowall and Saunders, 2010). First, the theory assumes that firms within an industry operate on different competitive edge depending on the capability of the resource that they control. Secondly, it assumes that since a firm's resources are not mobile or traded within an industry, thus, a company can retain a competitive edge acquired through firm resources for a long period of time (Olusanya, Awotungase and Ohadebere, 2012).

The emphasis of the theory, therefore, is that firms within an industry or strategic group compete with different resources 
with regard to human beings and thus, will have a different competitive advantage. This means that if all firms in an industry have the same type of human resources, then all firms would operate on the same kind of competitive edge which may deter continuity and the success of an industry. The RBV theory is an essential measure of human resource efficiency for a firm's competitive advantage and performance within a firm's strategic group (Ezeani and Oladele, 2013). This shows that human efficiency within an organization is determinant of what becomes the fate of an organization within an industry. Human efficiency within an organization is expected to deliver different results for an organization in order to satisfy the needs of customers at an agreed cost. According to Barney (1991), the immobility and non-transferability of resources are not enough to ensure sustainable competitive advantage for firms within a strategic group. This means that for firms to achieve and experience a sustainable competitive advantage, its resources need to be rare and valued from the eyes of customers and improperly imitable and substitutable from the eyes of competitors (Obi-Anike and Ekwe, 2014). This theory is relevant to the proposed study because it emphasizes the importance of human resources efficiency at work and its effects on organization performance and sustainable competitive advantage. Thus, human resource efficiency in an organization cannot be overemphasized as it determines the success and or failure of an organization.

\section{Inefficiency in Nigerian Universities}

The non-academic department in a university system consists of works, bursary, librarian, medical personnel, exams and records, confidential secretaries, cleaners/messengers, administrative staff, account, security personnel among others. Many of these departments are greatly inefficient at their capacity to function effectively and support the university system to achieve its stated objectives and goals especially in state and federal universities in Nigeria (Iwuoha, 2018). For instance, exams and record department in Nigerian universities have a long history and mismanagement of student's results and preparing academic transcripts for students. This inefficiency has gone so deep to an extent where foreign universities or organizations will send a mail to exams and records department to confirm a student's academic status and will not get any response. Furthermore, a student will be processed for National Youth Service Corp (NYSC) and when the student comes back to request for his/her academic transcript, that when the exams and record department will found out that the students have a missing result.

Additionally, the bursary department will allocate a project or work to a contractor and bring up different stories and the issue of no funds after job completion. Furthermore, the department of works is seen as a department filled with incompetent staff who cannot successfully carry out a task especially with regard to employees who uses low-quality materials to execute a task (Samuel and Chipunza, 2009). This incompetence has become a general symptom in public institutions and organizations in Nigerian and this is because the recruitment process for this staffs is not based on the need for job performance in the organization but to satisfy top-ranking officers who have relatives that need employment opportunities (Moulik and Mazumdar, 2012). Similarly, most confidential secretaries in universities have no knowledge and capacity to handle computers or successfully preside over meetings such that they can take and read minutes of meetings. This issue of inefficiency among non-academic staff has become a menace and has damaged the university image both in the domestic and global level. It has even brought a set back to the academic activities in the universities (Samuel and Chipunza, 2013). The inefficiency among non-academic staff units such as exams and records, works and bursary among others are regarded to be lack of effective training and development and sometimes due to wrong placement and recruitment of staff.

Training and development as it is said that is an essential tool necessary for organization growth and survival especially in a dynamic and ever-changing business environment. Training and development are important for a university administrator to be effective and efficient at the work they do for the organization. This means that lack of training and development of university administrators would hinder the success and educational services of a university system and this would affect the rating and attraction of the university to the international community. Notably, inefficient training and development of employees among state and federal university administrators in Nigeria are attributed to lack of strategic career planning and growth, lack of adequate infrastructural facility and inadequate tools for employees to effectively perform at work (Diefendorff et al., 2018).

\section{Non-Academic Staff Training and Development}

There are several methods of training and development employed by most organizations to gauge employee job inefficiency. These methods are dependent on several factors such as organization's need, job performance needs, job duration, number of employees to be trained, the relative impact of the training among others (Oyeniyi, 2011). However, the most commonly used method of training in organizations of today is on-the-job-training, team-training, creativity, diversity, customer relationship management training among others. We also have off the job training such as employee induction, workshops, seminars, mentorship training among others. Some of these methods are usually not a common practice of most organizations as a way of gauging employee inefficiency but are recognized as a direct or indirect method used for employee training (Engetou, 2017). Additionally, training has been categorized into two different types; preservative and inservice-training. Preservative training is usually educational in nature as it is usually conducted by a formal organization where the participants are required to learn based on structured syllabus and contents for a particular period of time to acquire a formal degree or certificate. While in-service-training is consistently offered by organizations to all its employees for the purpose of improving employee's performance as it's related to organization activities (Emeti, 2014).

University management can enhance the non-academic staff functions by providing comprehensive job-specific training to all its administrative staff. This is only possible when an organization conducts job-specific assessment and performance 
evaluation to determine the needs of each position as it relates to the type of employees required to occupy identified positions in the organization. This will help the university to determine the type of training needed and the right method appropriate for training non-academic staff for better performance on the job. Research has shown that organizations that train its employees to be problem-solvers, decision-makers, and enhance their interpersonal skills perform optimally on the job and improve organization competitive edge (Raja, Furqan and Muhammad, 2011). The current business environment is moving at an increasingly fast pace due to technological innovation and organizations that are not abreast of this reality are gradually going into extinction. Therefore, training nonacademic staff on the use of some technology to get the job done is not a question required for debate but a must for an organization who want to excel both in the local and foreign environment.

Furthermore, there are many factors that determine the rating of an institution some of which are; research orientation and availability on the internets, quality of faculty members and international recognition and citation, teaching reputation, international student's attraction, and students' ratio. All of these rating criteria for university, directly and indirectly, involve the work and skills of non-academic staffs within an institution (Niazi, 2011). Thus, neglecting the training of nonacademic staff training to be better equipped with the relevant technological equipment necessary for better performance on the job is at the peril of the university. It has been observed that non-academic staff training, especially in public universities in Nigeria and Africa as a whole, has been greatly neglected and ignored for several reasons. Meanwhile, effective and efficient performance is always expected from these staff as a result of the dynamic business requirement which imposes the use of technology as a means of getting work done in faster and easier ways. Hence, employees who are not trained especially on the use of these technologies are not expected to perform optimally on the job (Ndibe, 2014).

\section{Employee Productivity and Quality of Service Delivery}

According to Odhiambo, Njanja, and Zakayo (2014), the inefficiency of most employees in the organization can be traced directly to the recruitment and placement strategy adopted in the organization which sometimes is a result of an indirect linkage of employee capability and the job description and organization objectives. It is important to state that employee productivity has a direct impact on organization productivity as the former dictate the tone and direction with which the later will take. This is because of the overall productivity that an organization record within a year shows the extent of performance and productivity of individual employees within an organization (Papa et al., 2018). It is therefore important to recruit the right employees for a job position in the organization. Recruitment is the process of employing or engaging the best-qualified individuals which may be internal or external recruitment for an organization. It is the technique to discover the best workforce to meet the essential staffing plan and to use fruitful measures for attracting labor in adequate numbers in order to empower appropriate skills for a beneficial working power for the organizations (Dash and Mohapatra, 2016).

Furthermore, the quality of service delivered by employees in the organization can also be traced to the efficiency and effectiveness of the recruitment process with regard to job skills and placement strategy adopted. Employees that are placed on a job that does not match his/her skills will not perform up to the standard expected in the organization. However, the quality of service delivered to customers-clients of the organization indirectly determines the return purchase of such customersclients which at the end impact positively or negatively on the overall performance of the organization. Thus, training and development can serve as the missing link to gauge underproductive employees and employees whose work standard and service delivery are below expectations in the organization (Papa et al., 2018).

\section{Problem Statement}

Administrative/personnel inefficiency is a menace to the growth and success of a business enterprise. Inefficient employees or departments in an organization can cause a total breakdown in the flow of activities and the achievement of timely organizational results. Inefficiency directly relates to inadequate manpower or resources used in an organization (Barzegar and Farjad, 2011). Thus, managerial inefficiency is a waste of manpower or resources by an individual or department in an organization. The inefficiency of employees or departments can be determined or measured from the results achieved from the set task and the standard given to such employees or departments from the inception of the task. This is why inefficiency in an organization is directly linked to the lack of adequate training and development of employees in an organization (Khan, 2015). Inefficiency is practically prevalent among the non-academic staff of most federal and state universities in Nigeria especially when it comes to effective and efficient administrative handling of academic activities with regard to issues concerning students, academic staff, financial planning, budgetary system/ allocation, manpower coordination, and planning system. The lack of effective structure and the rigid bureaucratic system being practiced by these public universities coupled with managerial incompetence of non-academic staffs contributes to the dissatisfaction experienced by students and stakeholders in domestic and international communities (Lee, Lee and $\mathrm{Wu}$, 2010).

\section{Research Questions}

1. How does induction training significantly impact the quality of nonacademic staff's service delivery in Nigerian Universities?

2. What specific impacts does on-the-job training has on nonacademic staffs' quality of service delivery in Nigerian Universities?

3. Does formal training significantly impact non-academic staff productivity in Nigerian Universities?

4. To what extent does demonstration training significantly impact employee productivity in Nigerian Universities? 


\section{Research Hypotheses}

$\mathbf{H}_{01}$ : induction training has no significant impact on quality of non-academic staff's service delivery in Nigerian universities $\mathbf{H}_{02}$ : on-the-job training has no significant impact on non-academic staff's quality of service delivery in Nigerian universities

$\mathbf{H}_{03}$ : formal training has no significant impact on non-academic staff productivity in Nigerian universities

$\mathbf{H}_{04}$ : demonstration training has no significant impact on employee productivity in Nigerian universities

\section{MATERIALS AND METHODS}

\section{Data Collection Procedure}

This study is purely quantitative because it adopts the use of a questionnaire as a method of gathering data to test hypotheses earlier stated in the study. The population of the study are selected non-academic staffs of federal and state universities in Nigeria. Thus, three federal universities and three state universities are selected for the study. Fifty non-academic staff who are permanent staff are selected from each of these universities making a total of three hundred non-academic staffs. The justification for selecting fifty respondents from each of the universities selected for study is because the study adopts convenience and stratified sampling technique and this enables the researcher to select respondents based on ease of access and based on some predefined selection criteria of non-academic staffs. The questionnaire was distributed to selected nonacademic staff of Nigerian universities who meet the selection criteria based on the sampling technique and the distribution took a period of 3 weeks with the aid of three research assistants.

\section{Instrumentation}

The questionnaire used for the study were guided by established scale in literature. Hence, employee productivity scale was adapted from (Buuri, 2015; Leitão, Pereira, and Gonçalves, 2019), quality service delivery scale was adapted from (Parasuraman, Zeithaml and Berry, 1986) while training and development scale were adapted from (Demo et al., 2012). The scale was guided by a five point likert scale response type of strongly agree, agree, undecided, disagree and strongly disagree. The study adopts the use of statistical package for social sciences (SPSS), exploratory factor analysis (EFA), confirmatory factor analysis (CFA) and structural equation model (SEM) as a method of data analysis. SPSS was used to analyze respondents' demographic profiles such as (Sex, Gender, work experience among others), EFA was used to reduce redundant items and check the underlying questions and dimensions adapted from literature for each constructs of the study while CFA was used to determine the fitness of the model which is the determining criteria before using SEM to test the hypotheses stated in the study. SEM is appropriate to test the hypotheses stated in this study because the purpose of the study is to examine the significant connection existing between training and development of non-academic staff and their managerial efficiency in Nigerian tertiary institutions. A pilot study was conducted by selecting sixty respondents across the selected universities in order to confirm the reliability and validity of the instruments and the results revealed 0.84 which is above 0.70 as suggested by Nunnally (1978) as the threshold point for instruments reliability.

\section{Context and Participants}

The researcher administered three hundred questionnaires across the selected universities in Nigeria and only two hundred and ninety-three questionnaire were successfully returned and used for the analysis. The response shows that $39.5 \%$ are female while $60.4 \%$ are male. Furthermore, $13 \%$ of the respondents are below 25 years of age, $71.3 \%$ are between $25-30$, and $15.7 \%$ are between 31-40. Respondents marital status shows that $76.1 \%$ are married while $23.9 \%$ are single which shows that majority of the respondents are married. Similarly, response based on educational qualification of respondent's shows that $48.5 \%$ are $\mathrm{HND} / \mathrm{BSC}$ holder, $32.1 \%$ have $\mathrm{MBA} / \mathrm{MSc}$ while only $19.4 \%$ have either $\mathrm{PhD} / \mathrm{DBA}$ among the selected staffs. Additionally, $23.8 \%$ of the respondents have less than 5 years of work experience, $56.7 \%$ have between $6-10$ years, $12.6 \%$ have between $11-15$ years while $6.8 \%$ have above 16 years of work experience in the organization. Furthermore, $31.7 \%$ work in the department of accounts/bursary, $21.5 \%$ work in exams and record department, $12.2 \%$ work in library, $3.7 \%$ work in maintenance while $30.7 \%$ work in the department of works. Finally, $17.1 \%$ of respondents work as a confidential secretary, $29.7 \%$ work as a librarian, $32.1 \%$ work as an administrator while $20.5 \%$ work as an engineer.

\section{DATA ANALYSIS \\ Exploratory Factor Analysis}

Exploratory factor analysis was conducted using the principal axis factoring since the objectives were to examine the relationship between items or factors (Bandalos and Finney, 2010). Oblique rotation was performed to theoretically affirm the overlap expected to occur from the set subscales of the study. Oblique rotation is usually performed when the results from the EFA is expected to be used for conducting CFA as the EFA results are anticipated to allow a correlated latent factor (Matsunaga, 2010). Thirty-five items were subjected to principal axis factoring from the first loading and four items failed to load properly as the figure was not greater than 0.4 , therefore, they were excluded from the factor arrangement. Hence, the remaining thirty-one items were subjected to eigenvalues greater than one and were considered for the second-factor loading using (principal-axis with direct oblimin-rotation). Therefore, five items were again excluded from the factor structure with eigenvalues greater than one making a total of twenty-six factor retained for CFA analysis. The EFA results (see table 1) with regard to the Kaiser-MeyerOlkin having ( 0.686$)$, which is above 0.5 as recommended by Orçan and Yang (2016); Bartlett's test of sphericity is 0.000 and it is statistically significant at $p<0.05$, which means that there is a correlation between the tested variable, the degree of freedom is 190 and the chi-square value is 5,661.922. Furthermore, the EFA results further revealed the extraction communalities which is displayed below for the accepted twenty-six factors for CFA analysis and shows the extent of the correlation between the accepted items. The accepted factors all have a value greater than 0.4 as recommended by (Bandalos and Finney, 2010; Beavers et al., 2013) before conducting confirmatory factor analysis. 


\begin{tabular}{lcc|c|c|c|c} 
& $\boldsymbol{X}^{2}$ & $\boldsymbol{D} f$ & Bartlett's test of Sphericity & $\boldsymbol{p}$-value & KMO \\
\hline Measurement Value & 5661.922 & 190 & .000 & 0.05 & .686 \\
\hline Recommended Value & $\boldsymbol{V}$ & $\boldsymbol{V}$ & $\boldsymbol{V}$ & $\boldsymbol{V}$ & $>0.5$ \\
\hline
\end{tabular}

Table 1: Results of EFA Measures

\section{Confirmatory Factor Analysis}

The study conducts a confirmatory factor analysis (CFA) with twenty-six factors accepted from the results of EFA in order to determine the fitness of the model which is the first criteria before conducting a structural equation model (SEM). From the observed variables of induction training, two items were deleted (IT5, IT6), from the observed variable of on-the-job training one item was deleted (OJT5). Moreover, one item was deleted from the observed variable of demonstration training (DT1), while, two items were also deleted from the observed variable of employee productivity (EP1, EP4). The results of the composite reliability $(\mathrm{CR})$ and the average variance extracted (AVE) for each of the variable tested is above 0.70 and 0.50 which is the baseline threshold as recommended by (Bagozzi and Yi, 2012) and this shows that the model is reliable. Furthermore, the results of the Cronbach alpha are greater than 0.70 as recommended by (Nunnally, 1978) as the threshold of acceptance.

\begin{tabular}{|c|c|c|c|c|c|c|c|}
\hline Constructs & & Mean & Standard Deviation & Item-Total Correlation & Cronbach Alpha & CR & AVE \\
\hline \multirow{4}{*}{ Induction Training } & IT1 & 3.46 & 1.124 & 0.641 & \multirow{4}{*}{.850} & \multirow{4}{*}{0.831} & \multirow{4}{*}{0.556} \\
\hline & IT2 & 3.77 & 1.249 & 0.767 & & & \\
\hline & IT3 & 3.68 & 1.387 & 0.698 & & & \\
\hline & IT4 & 3.79 & 1.310 & 0.664 & & & \\
\hline \multirow{4}{*}{ On-the-Job Training } & OJT1 & 3.78 & 1.437 & 0.562 & \multirow{4}{*}{.821} & \multirow{4}{*}{0.798} & \multirow{4}{*}{0.505} \\
\hline & OJT2 & 4.04 & 1.267 & 0.783 & & & \\
\hline & OJT3 & 4.22 & 1.202 & 0.601 & & & \\
\hline & OJT4 & 3.92 & 1.197 & 0.650 & & & \\
\hline \multirow{3}{*}{ Demonstration Training } & DT2 & 3.26 & 1.080 & 0.679 & \multirow{3}{*}{.857} & \multirow{3}{*}{0.748} & \multirow{3}{*}{0.503} \\
\hline & DT3 & 3.36 & 0.989 & 0.797 & & & \\
\hline & DT4 & 3.22 & 1.026 & 0.721 & & & \\
\hline \multirow{4}{*}{ Formal Training } & FT1 & 3.08 & 1.060 & 0.828 & \multirow{4}{*}{.892} & \multirow{4}{*}{0.921} & \multirow{4}{*}{0.745} \\
\hline & $\mathrm{FT} 2$ & 3.08 & 1.052 & 0.819 & & & \\
\hline & FT3 & 3.14 & 1.095 & 0.811 & & & \\
\hline & FT4 & 3.17 & 1.095 & 0.812 & & & \\
\hline \multirow{2}{*}{ Employee Productivity } & EP2 & 4.10 & 0.649 & 0.615 & \multirow{2}{*}{.747} & \multirow{2}{*}{0.716} & \multirow{2}{*}{0.582} \\
\hline & EP3 & 4.03 & 0.812 & 0.682 & & & \\
\hline \multirow{3}{*}{ Quality Service Delivery } & QSD1 & 3.96 & 0.824 & 0.756 & \multirow{3}{*}{.859} & \multirow{3}{*}{0.863} & \multirow{3}{*}{0.678} \\
\hline & QSD2 & 3.99 & 0.754 & 0.718 & & & \\
\hline & QSD3 & 4.04 & 0.669 & 0.744 & & & \\
\hline
\end{tabular}

Note: CR: Composite Reliability, AVE: Average Variance Extracted, MSV: Maximum Shared Variance.

Table 2: Reliability Measures Source: Field Survey, 2019

\begin{tabular}{lcc|c|c|c|cccc} 
& $X^{2}$ & $D f$ & $p$-value & CFI & TLI & IFI & GFI & RMSEA \\
Measurement Model & 2.848 & 190 & $<0.001$ & .910 & 899 & .900 & .920 & .07 \\
\hline Recommended Value & $\leq 2$ or 3 & & & $>.9$ & $>.9$ & $>.9$ & $>.9$ & $<.05$ to. 08 \\
\hline
\end{tabular}

\section{Table 3: Results of CFA}

Generally, the measurement model fit the data well as $\left(X^{2} / d f=2.848, \mathrm{IFI},=.900, \mathrm{CFI}=910, \mathrm{TLI}=899, \mathrm{GFI}=.920\right.$ and RMSEA $=.07$ ) which according to (Hair et al., 2017; Nusair and Hua, 2010; Sivo et al., 2006) are a good indication of measurement fitness, where, $\left(X^{2} / d f\right)$ represents the chi-square, (IFI) represents incremental fits index, (CFI) represents comparative fits index, (TLI) represents tucker lewis index and (RMSEA) represents roots mean square error of approximation. Therefore, the model fit assessment using CFA shows that it is reliable and surpassed the threshold for conducting a structural equation model in order to reject or not reject the stated hypotheses. Hence, the study tests the hypotheses using a structural equation model.

\section{Results of the Hypotheses Testing (Path Modelling/SEM)}

Four hypotheses are posited in this study and literature confirms that when $p<0.05$ are a good indication that there is a significant relationship among measured and latent variables which then leads to either rejecting or not rejecting the hypothesis (Chinomona et al., 2010). 


\begin{tabular}{|c|c|c|c|c|c|c|c|c|}
\hline \multicolumn{3}{|c|}{ Hypothesized Model } & $R$ & $R^{2}$ & B & Beta & $t$ & significance \\
\hline $\mathrm{H}_{01}$ Induction Training & $\longrightarrow$ & Quality Service & .592 & \multirow{2}{*}{.241} & 0.15 & 0.567 & 3.234 & $* * *$ \\
\hline $\mathbf{H}_{02}$ On the Job Training & $\longrightarrow$ & Quality Service & .731 & & -0.20 & -0.671 & -4.454 & $* * *$ \\
\hline $\mathbf{H}_{03}$ Formal Training & $\longrightarrow$ & Employee productivity & .692 & \multirow{2}{*}{.312} & -0.29 & -0.679 & -5.604 & $* * *$ \\
\hline $\mathbf{H}_{04}$ Demonstration Training & $\longrightarrow$ & Employee productivity & .675 & & 0.23 & 0.789 & 6.760 & $* * *$ \\
\hline
\end{tabular}

Table 4: Hypothesized Model and Multiple Regression Coefficients

The table (see table 4) highlighted the hypothesized model in the order of their hypotheses as stated in the path analysis conducted in the study. Additionally, the table (table 4) also summarized the multiple regression coefficients from the output of structural equation model where $R$ represents the correlation output, $R^{2}$ represents the squared multiple correlation output, $\beta$ represent the unstandardized coefficients, and beta represent elements of the standardized coefficients, $t$ represent the $t$-statistics and $* * *$ in the column significance means the level of significance, which is at 0.05 .

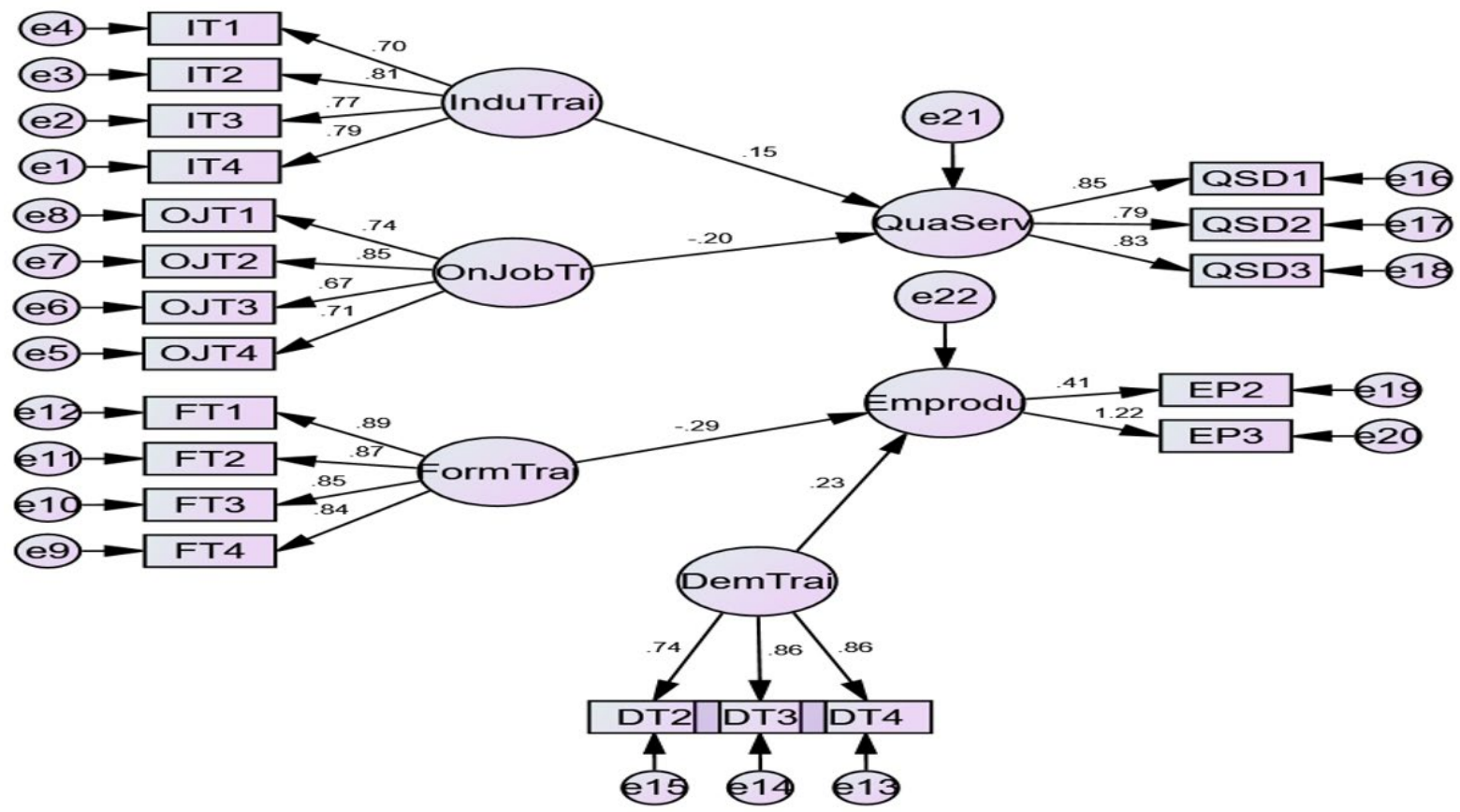

Figure 1: Showing Standardized Estimated Hypothetical Path Model

Path hypothesis one: this hypothesis tries to examine if induction training has any significant impact on the quality of service delivery of non-academic staffs in Nigerian universities. The result (see table 4) shows a positive relationship among tested variables, hence, the hypothesis is not rejected at $t=3.234(p<0.05)$ and $\beta=0.15$. The finding indicates that employee benefits from the training giving to them at the points of entry into the organization. This finding is consistent with the study of Chen, Wang and Yang (2009), Khan (2015), Rizov and Croucher (2009) and Qureshi et al. (2010) and take a direct queue with the finding of Amin et al. (2014). Furthermore, the relationship between subscales and other latent variables for the purpose of this construct is consistent with the result of the study as there exist a positive relationship among subscales and other latent variables.

Path hypothesis two: this hypothesis tries to examine if on-thejob training has any significant impact on the quality of service delivery of non-academic staffs in Nigerian universities. The result (see table 4) shows a negative relationship among tested variables, hence, the hypothesis is not rejected at $t=-4.454$ $(p<0.05)$ and $\beta=-0.20$. The indirect and or negative impact of this hypothesis could be as a result of factors not tested in the study but which affect employee especially as it relates to their experience of on-the-job training in the organization. Although, the hypothesis tested for this study has a negative relationship but there exist a positive relationship between subscales and other latent variables for the purpose of this construct.

Path hypothesis three: this hypothesis tries to examine if formal training has any significant impact on employee productivity in Nigerian universities. The result (see table 4) shows a negative relationship among tested variables, hence, the hypothesis is not rejected at $t=-5.604(p<0.05)$ and $\beta=-0.29$. This finding does not align with the work of Obi-Anike and Ekwe (2014) who found that the impact of formal training on employee productivity cannot be overemphasized as they consistently seek to help an organization achieve sustainable competitive advantage. Additionally, the relationship between subscales and other latent variables for the purpose of this 
model show a positive relationship, which is not consistent with the finding of the hypothesis tested.

Path hypothesis four: this hypothesis tries to examine if demonstration training has any significant impact on employee productivity in Nigerian universities. The result (see table 4) shows a positive relationship among tested variables, hence, the hypothesis is not rejected at $t=6.760(p<0.05)$ and $\beta=0.23$. This hypothesis shows a positive impact relationship which may be due to the effect of demonstration work impact on employee productivity. Finally, there exists a positive relationship between subscales and other latent variables for the purpose of this construct and it is consistent with the finding of the hypothesis.

\section{DISCUSSION}

The purpose of this study was to examine how training and development can improve non-academic staff work efficiency in selected public universities in Nigeria. Four path hypotheses were proposed for the study and four elements of training and development (induction, on-the-job, demonstration and formal training) served as the independent variable while the dependent variable which is managerial efficiency were considered looking at (quality of service delivery and employee productivity). From the four hypotheses proposed, hypothesis one and four shows a positive significant impact while hypothesis two and three shows a negative impact.

Finding from the first research question revealed that there is a significant impact between induction training and the quality of service delivery in Nigerian public universities. This is because the majority of the respondents attest to the fact that induction training given to them at the point of job entry significantly aids their performance on the job. This is further corroborated with the result of the hypothesis tested for the construct. They, however, could not affirm the willingness and adequate preparation given to their training induction by the management of the university as is mostly found in the practice of private organizations. Induction training is specifically important because it's the first practical knowhow that new employees are exposed to at the point of entry into an organization. However, this finding does not support the work of Dialoke, Adighije, Nkechi (2017) an Engetou (2017) who found that most public organizations especially tertiary institutions do not officially carry out induction training for new employees (non-academic staffs). A current employee is usually appointed to show new employees the way to their department and the staff he or she is supposed to report to and this is done without any structured or formal training at the point of entry. Although, the finding supports the work of Abeba, Mesele and Lemessa (2015) and Amin et al. (2014). Induction training, however, represents the first training that employee receives from an organization and the purpose is to help new employees to settle in well on their new job.

The study also found from the second research question that on-the-job training has a significant negative relationship with the quality of service delivery in Nigerian universities. This could be because most Nigerian universities do not deliberately position new employees to learn directly from the current employee in order to improve their performance. Moreover, current employees, most times see new employees in their department as a threat to their job/position and thus, may refuse to share knowledge and information that would help new employees to improve performance (Moulik and Mazumdar, 2012). However, this finding is in alignment with the work of (Mungathia, 2019; Yusuf, Makera, and Kamaruddeen, 2019). Finding also revealed that Nigerian university management sees non-academic staff training as an exercise that is not worth investing on and thus, do not have any budget catering for the training of non-academic staffs. Hence, non-academic staff is left to personally seek means to improve their performance on the job and this is why inefficiency has plagued the activity of non-academic staff in Nigerian universities especially workers who naturally exhibit "I don't care attitude". Furthermore, the belief that government job is the most secure job and no senior staff can sack them for inefficient performance on the job contribute hazard to the inefficient behaviour experienced from most civil servants in Nigeria (Chen, Wang and Yang, 2009). Similarly, the study also found from the third research question that a negative impact exists between formal training and employee productivity in the organization. This finding supports the work of scholars such as Bassey Owan and Agunwa (2019), Samuel and Chipunza (2013) and Tettey (2010) who found that training employees to perform optimally will significantly improve employee productivity/efficiency and directly enhance organizational growth and industry competitive advantage. However, this is usually not the case especially if the objective of formal training of employees is not well defined. This finding also aligned with common sense such that employee who is not performing very well in the organization need to be trained. Formal training is a deliberate act engaged upon by an organization to gauge an inefficient part of the employee to perform optimally for an organization (Barzegar and Farjad, 2011). Finding also revealed that most employees in Nigerian public universities have not been formally scheduled for formal training since they started work which is why most of them has been struggling to keep up with changing work conditions as a result of technological innovation.

Finally, finding from the fourth research question also revealed that demonstration training has a significant positive relationship with employee productivity in Nigerian universities. This could be because demonstration as a form of training requires some level of willingness by a senior member of an organization and even the top management to train young employees on the use of some tools in order to aid better performance and this is usually not the case in most public tertiary institutions in Nigeria (Bassey, Owan and Agunwa, 2019). Demonstration training is a practical way of teaching and imparting knowledge to employees and this is because it involves direct learning from an instructor in an organization. Respondents affirmed that the only demonstration training experienced is when they walk up to a senior member of their department to teach them on the use of some tools to aid efficiency at work especially when they are having difficulty using those tools/equipment to deliver on their job. 


\section{CONCLUSION}

The issue of training and development of employees has become a vital tool in organizational growth and sustainable development especially with regard to public tertiary institutions in Nigeria. The reason is that the business environment is dynamically taking a new turn every day and technology is setting a new standard for job delivery and operational efficiency. Thus, an organization that wants to compete effectively and remain relevant in its industry must constantly seek to train and retrain its workforce in order to be abreast of technology advancement and its mode of getting work done in organizations. The inefficiency that has plagued the Nigerian public institutions has been found in this study to be as a lack of proper management training and development of nonacademic staffs and extant literature has discussed extensively the importance of training and development on managerial efficiency, productivity and effectiveness and showed its relative impact on organizational sustainability and survival (Abeba, Mesele. and Lemessa, 2015; Dialoke Adighije and Nkechi, 2017; Olusanya, Awotungase and Ohadebere, 2012). Furthermore, the issue of inefficiency among non-academic staffs in Nigerian tertiary institutions as researched in this study can be traced to many factors such as corruption, nepotism, mismanagement, bureaucratic bottle-neck among others and this has dogged the inefficient services and productivity of these institutions (Yusuf, Makera, and Kamaruddeen, 2019). Therefore, Nigerian public institutions need to be intentional to create an enabling work environment for non-academic staffs that seek to improve employee's skills and capability through training and development to enhance employee career growth which directly and indirectly improves institution's domestic and international rating.

\section{POLICY IMPLICATION}

The reason why inefficiency has plagued the services of public organizations especially tertiary institutions in Nigeria is majorly due to factors such as nepotism, corruption and bottle-neck bureaucracy (Tettey, 2010). Employing based on family and individual needs and not based on the job-specific needs to kill efficiency and productivity for an organization. Public universities need to promote a scientific selection and recruitment of employees in order to eradicate people's person syndrome to employment, which has caused a lot of harm to the efficient operations of non-academic activities in public universities in Nigeria (Amin et al., 2014). The finding of the study shows that induction training contributes immensely to employee performance on the job and thus needs to be carefully encouraged for better performance to be consistently experienced from all employees (Abeba, Mesele and Lemessa, 2015). Moreover, employee promotion needs to be based on structured performance evaluation and feedback needs to be cheered in order to help non-performing employees examine his/her grey areas and work towards meeting set performance standards in the organizations.

It is believed that the activities of most Nigerian universities especially federal and state are controlled or ratified by the federal and or state government. Hence, the government needs to enforce a consistent training and development for both academic and non-academic staffs through a substantial budgetary allocation aimed towards improving the standards of civil servants to be at par with international universities at least once every year. This is important because the world is fast changing especially with the fourth industrial revolution setting new standards for job operations (Ng'ethe et al., 2012). Nigerian public universities need to keep abreast of this technological development and equip its administrative or non-academic workforce to deliver optimally and help project the institutions in such a way that it would improve the rating and standard of the university both locally and within the international community.

Furthermore, the finding of the study shows a negative relationship exists between on-the-job training and quality of service delivery. Many of the articles reviewed show a positive relationship existing between on-the-job training and employee performance which can be liking to quality of service delivery in the private organization (Abdullah, Ahsan and Alam, 2009). This, however, shows the importance of on-the-job training process that private organization has been adopting to gauge employee inefficiency and enhance standards performance of employees to be at par with what is required to compete with rival competitors. Thus, Nigerian universities need to be intentional with attaching underperforming employees to learn directly from a high performing employee at the university. They also need to eradicate the fear of senior employees losing their job or delayed promotion which make many senior performing employees hoard knowledge and information from underperforming employees with the hope that his/her monopolized knowledge/performance on the job will automatically enhance his promotion chances to bigger positions (Barzegar and Farjad, 2011).

It is important to also state that training and development of non-academic staffs need to be designed based on the need of the job and not based on opportunity to extort training budget out of the university account for personal benefits as is the most corrupt practices of some top nonacademic officials in Nigerian universities (Khan, 2015). Employees' training and development need to be designed to enhance and improve employee job efficiency and capability, which directly position the research and academic activities of the institution for development among relevant stakeholders. For improved job efficiency and productivity, the HR department of these public universities needs to set the standard for each administrative job and promotion needs to be strictly based on the standard set. There need to be clear and concise key performance indicators (KPI) which serve as guide and evaluation of employee objective performance. These measures are quite important to achieve administrative efficiency in the Nigerian public institutions as they are measures guiding employee's performance in private organizations (McDowall and Saunders, 2010). The federal and state government need to desist from the practice of conducting promotional examination for civil servants as this hinder objective employee's performance evaluation and feedback from direct and indirect supervisors of employee's and the HR department of the organization. This is because anyone can sit for exams and pass especially when the material for such exams is readily available for practices. 
Abdullah, Z., Ahsan, N. and Alam, S. S. (2009) 'The Effect of Human Resource Management Practices on Business Performance among Private Companies in Malaysia', International Journal of Business and Management, Vol. 4, No. 6, pp. 65-78. http://dx.doi.org/10.5539/ijbm.v4n6p65

Abeba, M. A., Mesele, D. A. and Lemessa, B. (2015) 'The Impact of Training and Development on Employee Performance and Effectiveness: A case study of District Five Administration Office, Bole Sub-City, Addis Ababa, Ethiopia', Journal of Human Resource and Sustainability Studies, Vol. 3, No. 4, pp. 188-202. http://dx.doi.org/10.4236/jhrss.2015.34025

Amin, M., Khairuzzaman Wan Ismail, W., Zaleha Abdul Rasid, S. and Daverson Andrew Selemani, R. (2014) 'The impact of human resource management practices on performance: Evidence from a Public University', The TQM Journal, Vol. 26, No. 2, pp. 125-142. https://doi.org/10.1108/TQM-102011-0062

Armstrong, M. (2009) Armstrong's Handbook of Human Resource Management Practice, $11^{\text {th }}$ edition, London: Kogan Page Limited.

Bagozzi, R. P., and Yi, Y. (2012) 'Specification, Evaluation, and Interpretation of Structural Equation Models', Journal of the Academy of Marketing Science, Vol. 40, No. 1, pp. 8-34. http://dx.doi.org/10.1007/s11747-011-0278-x

Bandalos, D. L., and Finney, S. J. (2010) 'Factor Analysis: Exploratory and Confirmatory', in G. R. Hancock and R. O. Mueller (Eds.), The reviewer's guide to quantitative methods in the social sciences, pp. 93-114, New York, NY: Routledge.

Barney, J. (1991) 'Firm Resources and Sustained Competitive Advantage', Journal of Management, Vol. 17, No. 1, pp. 99120. https://doi.org/10.1177/014920639101700108

Barzegar, N. and Farjad, S. (2011) 'A study on the Impact of on the Job Training Courses on the Staff Performance (a case study)', Procedia - Social and Behavioral Sciences, Vol. 29, pp. 19421949. https://doi.org/10.1016/j.sbspro.2011.11.444

Bassey, B. A., Owan, V. J. and Agunwa, J. N. (2019) 'Quality Assurance Practices and Students' Performance Evaluation in Universities of South-South Nigeria: a Structural Equation Modelling Approach', British Journal of Psychological Research, Vol. 7, No. 3, pp. 1-13.

Beavers, A. S., Lounsbury, J. W., Richards, J. K., Huck, W. S., Skolits, G. J., and Esquivel, S. L. (2013) 'Practical Considerations for using Exploratory Factor Analysis in Educational Research'. Practical Assessment, Research and Evaluation, Vol. 18 No. 6, pp. 1-13. https://doi.org/10.7275/ qv2q-rk76

Buuri, D.W. (2015) Performance Measurement Practices and Employee Productivity in the Insurance Firms in Kenya, [Thesis], School of Business University of Nairobi.

Chen, S.-H., Wang, H. H. and Yang, K.J. (2009) 'Establishment and Application of Performance Measure Indicators for Universities', The TQM Journal, Vol. 21, No.3, pp. 220-235. https://doi.org/10.1108/17542730910953004

Chinomona, R., Lin, J. Y.-C., Wang, M. C. H., and Cheng, J. M. S. (2010) 'Soft Power and Desirable Relationship Outcomes: The Case of Zimbabwean Distribution Channels'. Journal of African Business, Vol. 11, No. 2, pp. 182-200. https://doi.org/ $\underline{10.1080 / 15228916.2010 .508997}$
Dash, S., and Mohapatra, J. (2016) 'Employee Perception on the Role of HR for Creating and Managing Employer Branding Towards its Brand: An Explorative Study. Prabandhan': Indian Journal of management. Vol. 9, No. 2, pp. 10-25. https://doi.org/10.17010/pijom/2016/v9i2/87242

Demo, G., Neiva, E. R., Nunes, I., and Rozzett, K. (2012) 'Human Resources Management Policies and Practices Scale (HRMPPS): Exploratory and Confirmatory Factor Analysis'. Brazillian Administration Review, Vol. 9, No. 4, pp. 395-420.

Dialoke, I., Adighije, P., and Nkechi, J. (2017) 'Effects of Career Growth on Employees Performance: A Study of Non-Academic Staff of Michael Okpara University of Agriculture Umudike Abia State, Nigeria', Singaporean Journal of Business Economics, and Management Studies, Vol. 5, No. 7, pp. 8-18.

Diefendorff, J. M., Richard, E. M., Dinh, P. V., and LeNoble, C. (2018) 'Action-State Orientation at Work: Dynamic Effects in Organizational Contexts', in N. Baumann, M. Kazén, M. Quirin, and S. L. Koole (eds.) Why people do the things they do: Building on Julius Kuhl's Contributions to the Psychology of Motivation and Volition, p. 303-321, Boston, MA: Hogrefe Publishing.

Emeti, C. I. (2015) 'The Effects of Training/Development on the Performance of Paint Manufacturing Firms in Rivers State', European Journal of Business and Social Sciences. Vol. 4, No. 3, pp. 66-74.

Engetou, E. (2017) The Impact of Training and Development on Organizational Performance. Case Study, National Financial Credit Bank Kumba, [Thesis], Centria University of Applied Sciences Business Management, Unpublished.

Ezeani, N. E, and Oladele, R. (2013) 'Implications of Training and Development Programmes on Accountant's Productivity in Selected Business Organisations in Onitsha, Anambra State, Nigeria', International Journal of Asian Social Science, Vol. 3, No. 1, pp. 266-281.

Hair, J., Hult, G., Ringle, C., and Sarstedt, M. (2017) A Primer on Partial Least Squares Structural Equation Modeling PLSSEM, Los Angeles: SAGE.

Iwuoha, C.C. (2018) 'Impact of Training and Development Programmes on Secretaries' Productivity in Selected Business Organisations in Owerri, Imo state, Nigeria', Journal of School of Business and Management and Technology, Vol. 1, No. 1, pp. 106-110.

Khan, M.A. (2010) 'Effects of Human Resource Management Practices on Organizational Performance - An Empirical Study of Oil and Gas Industry in Pakistan', European Journal of Economics, Finance and Administrative Sciences, Vol. 24, pp. 157-175.

Lee, F. H., Lee, F. Z., and Wu, W. Y. (2010) 'The Relationship between Human Resource Management Practices, Business Strategy and Firm Performance: Evidence from Steel Industry in Taiwan', The International Journal of Human Resource Management, Vol. 21, No. 9, pp. 1351-1372. https://doi.org/1 $\underline{0.1080 / 09585192.2010 .488428}$

Leitão, J., Pereira, D. and Gonçalves, A. (2019) ‘Quality of Work Life and Organizational Performance: Workers' Feelings of Contributing, or Not, to the Organization's Productivity', International Journal of Environmental Research and Public Health. Vol. 16, No. 20, pp. 3803. https://doi.org/10.3390/ijerph16203803 
Mackelprang, A.W., Jayaram, J. and Xu, K. (2012) 'The Influence of Types of Training on Service System Performance in Mass Service and Service Shop Operations', International Journal of Production Economics, Vol. 138, No. 1, pp. 183-194. https://doi. org/10.1016/j.ijpe.2012.03.022

Matsunaga, M. (2010) 'How to Factor-Analyze Your Data Right: Do’s, Don'ts, and How-To's'. International Journal of Psychological Research, Vol. 3, No. 1, pp. 98-111.

Mathis, R. L., and Jackson, J. H. (2011) Human Resource Management, $14^{\text {th }}$ edition, Mason, $\mathrm{OH}$ : South-Western Cengage Learning.

McDowall, A. and Saunders, M. N. K. (2010) 'UK Manager's Conceptions of Training and Development', Journal of European Industrial Training, Vol. 34, No. 7, pp. 609-630. https://doi. org/10.1108/03090591011070752

Mungathia, F. M. (2019) 'The Challenges Encountered by the Selected Private Universities in Kenya in Implementing Strategies that would lead to a Financially Sustainable University', British Journal of Education, Vol. 6, No. 6, pp. 49-64.

Moulik, S. R., and Mazumdar, S. (2012) 'Exploring the Relationship between Perceived uses of Appraisal Satisfaction in the Indian IT Sector: An Empirical Study', International Journal of Business and Social Research, Vol. 2, No. 5, pp. 63-76. http://dx.doi. org/10.18533/ijbsr.v2i5.222

Ndibe, B. C. (2014) Effect of Employees Training on Organisational Performance in Soft Drinks Bottling Companies in Enugu State, Nigeria. Faculty of Business Administration, [Thesis], University of Nigeria Enugu Campus, Unpublished.

Ng'ethe, J. M., Iravo, M. E., and Namusonge, G. S. (2012) 'Determinants of Academic Staff Retention in Public Universities in Kenya: Empirical Review', International Journal of Humanities and Social Science, Vol. 2, No. 1, pp. 205-212

Niazi, A.S. (2011) 'Training and Development Strategy and its Role in Organizational Performance', Journal of Public Administration and Governance. Vol. 1, No. 2, pp. 42-57. https://doi.org/10.5296/ jpag.v1i2.862

Nunnally, J. C. (1978) Psychometric Theory, $1^{\text {st }}$ edition, New York: McGraw Hill.

Nusair, K., and Hua, N. (2010) 'Comparative Assessment of Structural Equation Modeling and Multiple Regression Research Methodologies: E-commerce Context', Tourism Management, Vol. 31, No. 3, pp. 314-324. https://doi.org/10.1016/j. tourman.2009.03.010

Obeidat, B. Y., Masa'deh, R., and Abdallah, A. B. (2014) 'The Relationships among Human Resource Management Practices, Organizational Commitment, and Knowledge Management Processes: A Structural Equation Modeling Approach', International Journal of Business and Management, Vol. 9, No. 3, pp. 9-26. http://dx.doi.org/10.5539/ijbm.v9n3p9

Obi-Anike, H. O, and Ekwe, M.C. (2014) 'Impact of Training and Development on Organizational Effectiveness: Evidence from Selected Public Sector Organisations in Nigeria', European Journal of Business and Management, Vol. 6, No. 29, pp. 6675.

Odhiambo, J. O., Njanja, Land Zakayo, C (2014) 'Effects of Succession Planning Practices on Organization Performance among the Non-Governmental Organizations in Kenya', European Journal of Business Management, Vol. 2, No. 1, pp. 141-154.
Olusanya, S. O., Awotungase, S. A., and Ohadebere, E. C. (2012) 'Training and Development, a Vital Tool for Organisational Effectiveness', Journal of Business and Management, Vol. 6, No. 2, pp. 48- 57. http://dx.doi.org/10.9790/487X-0624857

Oyeniyi, O. I. (2011) 'Human Resource Management in Nigerian Universities', [Thesis], Faculty of Education, Delta State University, Abraka, Unpublished.

Orçan, F., and Yang, Y. (2016) 'A note on the use of Item Parceling in Structural Equation Modeling with Missing Data', Journal of Measurement and Evaluation in Education and Psychology, Vol. 7, No. 1, pp. 59-72. http://dx.doi.org/10.21031/ epod.88204

Papa, A., Dezi, L., Gregori, G., Mueller, J. and Miglietta, N. (2018) 'Improving Innovation Performance through Knowledge Acquisition: the Moderating Role of Employee Retention and Human Resource Management Practices', Journal of Knowledge Management, https://doi.org/10.1108/JKM-092017-0391

Parasuraman, A., Zeithaml, V. and Berry, L. (1986) SERVQUAL: A Multiple-Item Scale for Measuring Consumer Perceptions of Service Quality, Report No. 86-108, Cambridge, MA: Marketing Science Institute.

Qureshi, M. T., Ayisha, A., Mohammad, A. K., Rauf, A. S. and Syed, T. H. (2010) 'Do Human Resource Management Practices Have an Impact on Financial Performance of Banks?', African Journal of Business Management, Vol. 4, No. 7, pp. 1281-1288.

Raja, A. G., and Furqan, A. K., Muhammad, A. K. (2011) 'Impact of Training and Development on Organisational Performance', Global Journal of Management and Business Research, Vol. 11, No. 7, pp.45-62.

Rizov, M. and Croucher, R. (2009) 'Human Resource Management and Performance in European Firms', Cambridge Journal of Economics, Vol. 33, No. 2, pp. 253-272. https://doi. org/10.1093/cje/ben037

Samuel, M. O., and Chipunza, C. (2009) 'Employee Retention and Turnover: Using Motivational Variables as a Panacea', The African Journal of Business Management, Vol. 3, No. 8, pp. 410- 415. https://doi.org/10.5897/AJBM09.125

Samuel, M. O., and Chipunza, C. (2013) 'Attrition and Retention of Senior Academics at Institutions of Higher Learning in South Africa: The Strategies, Complexities and Realities', Journal of Social Sciences, Vol. 35, No. 2, pp. 97-109. https:// doi.org/10.1080/09718923.2013.11893151

Sivo, S. A., Xitao, F., Witta, E. L., and Willse, J. T. (2006) 'The Search for "Optimal" Cutoff Properties: Fit Index Criteria in Structural Equation Modeling', Journal of Experimental Education, Vol. 74, No. 3, pp. 267-288. https://doi. org/10.3200/JEXE.74.3.267-288

Tettey, W. J. (2010) Challenges of Developing and Retaining: The Next Generation of Academics: Deficits in Academic Staff Capacity at African Universities, Alberta Canada: Faculty of Communication and Culture University of Calgary.

Yusuf, N. A., Makera, A. M., and Kamaruddeen, I. M. (2019) 'Assessing the Impact of Work Environment on Employee Engagement among Non-Academic Staff of the University', SEISENSE Journal of Management, Vol. 2, No. 1, pp. 23-40. https://doi.org/10.33215/sjom.v2i1.84 